УДК 811.161 .2

DOI: https://doi.org/10.17721/APULTP.2019.38.39-51

\author{
Olga O. Zlotnyk-Shagina \\ orcid.org/0000-0003-4367-7532
}

\title{
LITERARY LANGUAGE AND LITERARY NORM IN THE INTERPRETATION OF IVAN FRANKO
}

\begin{abstract}
The article deals with the concept of I. Franko on the development and functioning of the Ukrainian language and its dialects. On the basis of works of the author's works "Literary language and dialects" and "Speak of the wolf - say for the wolf", modern views on the problem of national and literary language have been formed. The historical-stylistic approach allows to comprehensively analyze Franko's views on key linguistic concepts - literary language and literary norm as well as a tangent to it - dialectal speech, linguistic flair, the culture of speech, etc. The role of I. Franko in the language disputes at the end of the 19th century is being outlined, in particular his work assesses and determines the role of the figure in the views of contemporary linguistic problems, the place of dialects in the language system, the dynamics of language processes at the end of 19th and beginning of 20th centuries, new trends in the development of lexical and phraseological fund of the Ukrainian language, the enrichment of the stylistic resource of the Ukrainian language, the role of socio-political processes on the state and quality of the Ukrainian language, etc. The author makes a digression to the life and work of I. Franko, specifically to scientific contacts with V. Jagić, $J$. Collares, M. Grushevsky which allowed to trace the interdependence in the problems of the formation and functioning of the literary language in Serbia and Croatia, Bosnia and Herzegovina, Montenegro, Slovenia, and Macedonia. Consideration of the "single Ukrainian language" for Franko is a key issue addressed in the works of both scientific and journalistic nature. It is important that both Franko and his contemporaries-Slavists, saw in the unity of the language a mental-national character of Ukrainians, which is confirmed by the epistolary heritage of the scientist and can be promising for further analysis of current problems of the Ukrainian language past and present.

Key words: literary language, literary norms, dialect language, Ivan Franko, idiostylistics, historical-stylistic paradigm.
\end{abstract}


Information about the author: Zlotnyk-Shagina Olga Oleksandovna - PhD, associate professor; Glier Kyiv Institute of Music; assistant of the department of Ukrainian and Russian languages as Foreign Languages; Institute of philology; Taras Shevchenko National University of Kyiv.

Електронна адреса: ozlotnik@bigmir.net

Злотник-Шагіна О.О.

orcid.org/0000-0003-4367-7532

\section{ЛІТЕРАТУРНА МОВА ТА ЛІТЕРАТУРНА НОРМА В ІНТЕРПРЕТАЦІЇ ІВАНА ФРАНКА}

Анотація. У статті розглядається кониепиія I. Франка щодо розвитку та функціонування украӥнської мови та ї̈ діалектів. На основі праць автора "Літературна мова та діалекти" та "Говоримо на вовка - скажімо $і$ за вовка" сформовані сучасні погляди на проблему національної та літературної мови. Історико-стилістичний підхід дозволяє комплексно проаналізувати думки Франка щедо ключових мовознавчих понять - літературна мова та літературна норма, а також дотичних до них - діалектна мова, мовне чуття, культура мови та ін. Визначається роль I. Франка в мовних дискусіях кін. XIX ст., зокрема дається оцінка та визначається роль діяча у поглядах на актуальні для сучасників мовознавчі проблеми. Зокрема, місие діалектів у системі мови, динаміка мовних процесів кін. ХIXпоч. ХХ ст., нові тендениії розвитку лексико-фразеологічного фонду украӥнської мови, збагачення стилістичного ресурсу украӥнської мови, вплив суспільно-політичних прочесів на стан і якість украӥнської мови тощя. Автором робиться екскурс в життя і творчість I. Франка, передусім у його наукові зв'язки з В. Ягичем, Я. Колларем, М. Грушевським та ін., що дозволило простежити взаємозалежності у проблемах становлення і функиіонування літературної мови Сербії та Хорватії, Боснії та Гериеговини, Чорногорії, Словенії і Македонії. Розгляд "єдиної української мови" для Франка - ключове питання, що аналізується у прачях як наукового, так і публіцистичного характеру. Важливо, що і Франко, і його сучасники-славісти, вбачали в єдності мови ментально-національний характер украӥнців, щуо ілюстровано епістолярною спадщиною науковия та може стати перспективним для подальшого аналізу актуальних проблем украӥнської мови. 
Ключові слова: літературна мова, літературна норма, діалектна мова, Іван Франко, ідіостилістика, історико-стилістична парадигма.

Інформація про автора: Злотник-Шагіна Ольга Олександрівна - кандидат філологічних наук, доиент; Київський інститут музики імені Р.М. Глісра; асистент кафедри украӥнської та російської мов як іноземних; Інститут філології; Київський національний університет імені Тараса Шевченка.

Електронна адреса: ozlotnik@bigmir.net

\author{
Злотник-Шагина О.А. \\ orcid.org/0000-0003-4367-7532
}

\title{
ЛИТЕРАТУРНЫЙ ЯЗЫК И ЛИТЕРАТУРНАЯ НОРМА В ИНТЕРПРЕТАЦИИ ИВАНА ФРАНКО
}

\begin{abstract}
Анотация. В статье рассматривается конщепция И. Франко относительно развития и функционирования украинского языка и его диалектов. На основе работ автора "Літературна мова та діалекти" и "Говоримо на вовка - скажімо $i$ за вовка" представлень современные взгляды на проблему национального и литературного языка. Историкостилистический подход позволяет комплексно проанализировать взгляды И. Франко на ключевые языковедческие понятия - литературный язык и литературная норма, а также относящиеся к ним - диалектная речь, языковое чутье, культура речи и др. Отмечается роль И. Франко в языковых дискуссиях кон. ХІХ в., в частности дается оценка и определяется роль деятеля во взглядах на актуальные для современников языковедческие проблемы: место диалектов в системе языка, динамика языковых процессов кон. ХІХ - нач. ХХ в., новые тенденции развития украинского лексико-фразеологического фонда, обогащение стилистического ресурса украинского языка, роль общественнополитических прочессов в истории Украинь и др. Автором делается экскурс в историю жизни и творчества И. Франко, в частности анализируются его научные связи с В. Ягичем, Я. Коллар, М. Грушевским и др., что позволило аргументировать взаимозависимость проблем становления и функиионирования литературного языка Сербии и Хорватии, Боснии и Гериеговины, Черногории, Словении и Македонии (ныне - Северной Македонии). Взгляд на "единство украинского языка" И. Франко - ключевой вопрос, который рассматривается как в научных, так и публицистических текстах автора. Важно, что И. Франко, как и
\end{abstract}


его современники-слависты, видели в единстве украинского языка ментально-национальный характер: это подтверждено эпистолярным наследием ученого и может стать перспективным для дальнейтего анализа актуальных проблем украинского языка.

Ключевые слова: литературный язык, литературная норма, диалектный язык, Иван Франко, идиостилистика, историкостилистическая парадигма.

Информация об авторе: Злотник Ольга Александровна кандидат филологических наук, дочент; Киевский институт музыки им. РМ. Глиера; ассистент кафедры украинского и русского языка как иностранного; Институт филологии; Киевский национальный университет имени Тараса Шевченко.

Электронный адрес: ozlotnik@bigmir.net

In the twenty-first century, the analysis of the scientific heritage of I. Franko, of an outstanding Ukrainian artist, linguist and literary critic, polemist and writer, literary critic and polyglot remains to be important. There are more than 20 linguistic works of Franko, which highlights his caring attitude to the national language, its features, and functional load. In his linguistic improvements, Franko argued that language is a way of communication between people that arose on the real ground.

In our study, we focus on four his works that are related to language functions and communication processes. This - "Children's words in the Ukrainian language", "Science and its position regarding the working classes" (works on the origin of language and its evolution during the formation of homo sapiens) and "Literary language and dialects" and "Talk to the wolf - let's say for the wolf" (work, which formed modern views on the problem of national and literary language).

The object of his linguistic studio was the speech of a child, which the scientist studied through the prism of the system of relations of the elements of the linguistic structure of word formation, the result of which was the scientific work "Children's words in the Ukrainian language". The development of children's language and the formation of language personality is the main task of modern education. According to Franko, it is the speech intentions in the speech of a child form the human linguistic consciousness and 
therefore is the first step to the exemplary literary language. To teach a child to use the means of language correctly and use it is the key to the success of modern society.

The exploration of "Science and its position regarding the working classes", in which a linguist has considered the question of the origin of human speech and its communicative functions. It is still the work of great value. This work refers more to the linguistic and philosophical sciences, which helps to understand the historical essence of the language today. Both works deal with the evolutionary processes of speech communication during the life of the author and the pre-author period.

In fact, these works constitute the initial interest of the author regarding the problems of the national identity of Ukrainians, our language in relation to culture. Defending the rights of the Ukrainian language to free and comprehensive development, the great patriot scientist in all his works and special studies on the Ukrainian language widely and skillfully used the facts of the Ukrainian language, considered the language to be a living organism that is constantly moving and developing.

The position of the Ukrainian literary language in modern times is confirmed by the author after the works "Talk to the wolflet's say for the wolf" (article- answer to B. Grinchenco) and "Literary language and dialects" (early twentieth century).

With the help of the mentioned above paradigmatic articles of Franko, it is possible to explore current views and form a coherent concept of the author on a key for each language of both: a system of the notion of literary language/ norm and post-literary elements. Franko sharply criticizes views of those who believed that there is no Ukrainian language, and there are only local dialects as part of one "great Russian language". At the same time, he supports young writers of Galicia, who began to create in lemkovskyi or boykivskyi dialects, noticing the following:

"we can only bless them on that road, in the belief that the deeper they will delve not only into people's speech but also into the essence of human life and the more talents appear between them on 
that field, the closer they will be to us and to our Ukrainian literature" $^{3}[7$, p. 208]

Thus, the scientist consistently studied and clearly distinguished social and territorial dialects, determined their features, described the peculiarities of the interaction of the literary language and dialects. Modern classification of the western-Ukrainian dialects was also established by I. Franko. It should be noted that the issue of the future general literary and national Ukrainian language has always been in the field of the view of the linguist. I. Franko denied a right to exist of moscophiles iazychie, emphasizing that literary language should be formed on a national basis. The scientist noted that the Ukrainian people should have one literary language, which will be based on the speech of Middle Naddnipryanschyna, as well as the language of I. Kotlyarevsky, G. Kvitka-Osnovyanenko, T. Shevchenko and other famous authors, whose language Franko considered to be exemplary.

At it is known, during the author's life, the state of the Ukrainian literary language was defined by the complex historical and political circumstances of the life of the Ukrainian people and associated with the previous stages of development of its language. It is stated in the studies of the following researchers: I. Matviyas [6], V. Greshchuk [1], S. Yermolenko [2], etc.

At that time, there were two versions of the literary language on the territory of Ukraine - East Ukrainian and West Ukrainian. Franko, as the representative of the second option, was forced to work in an environment where, along with the literary language based on folk, there was also a "iazychie" - a mixture of Church Slavonic, old Russian and pedantic Galician languages. It is possible to learn more about the history of the literary language in this period from the collective monograph of S. Bybyk, T. Kotz and others. [5].

Insisting on the interpretation of literary language as of a historically logical, socially important and a necessary form of the existence of the national language, researchers [5] emphasize its distinguishing features - over dialect character and dynamic stability

\footnotetext{
${ }^{3}$ Hereinafter the translation is ours
} 
standards, codification in dictionaries and grammars, multifunctionality and verbalized conceptual structure. Whereas Franko emphasizes the connection between the national language and norms, he calls literary language a "representative of national unity".

The artistic and linguistic practice of writers, according to S. Yermolenko [2; 5], as a criterion of formation and dynamics of the language norm is associated with the historical periods of the development of the Ukrainian literary language. Franko as an artist remains to be an exemplary carrier of the literary language, he is the most active creator of the national language in the sense that he deeply feels the finest movements of the folk word and reproduces the living word of the people. Understanding the phenomenon of the literary language as an indispensable component of the spiritual culture of Ukrainians is obviously connected with the development of national self-determination of Ukrainians, with the perception of written literature, which is created by the Ukrainian language. The basis of the language as of intellectual wealth of the language, Ivan Franko saw in a certain type of speech,

"in the vast area from Kharkov to Kamenets-Podolsk showed such uniformity, such as a marriage of drastic differences, which is fully consistent with the Ukrainian national style, also "mixed" and aligned in a mass, which has little similarities with any other type in the world. And everyone, either a Galician or a Ukrainian, who wants to say a printed word to the largest mass of the Ukrainian people, should use the language of that largest mass, and prior to that, the language produced by the largest number of talented and popular writers" [7, p. 206]

It should be noted that in the world studies of both literacy and linguistics, the figure of Franko as of a champion of the purity of the language is mentioned actively (see, eg., [3; 9]). In a global scientific context, Franko is known as a fighter for the freedom of language, where the role of dialects is defined as the source of literary language development (more widely in Franko's studies public spoken element, words and speech patterns of "specific national life"). Making efforts to the formation of Ukrainian literary 
language, I. Franko "found in the linguistic and literary dispute a democratic, broad approach, the foresight to eventually achieve unification, to bring together the born in the speech practice of different regions, and thus bring together the variant norms, if not overcome, then at least reduce the differences of cultural and ethnic character" [4, p. 410].

Another source of literary language development, according to Franko, were borrowings from other languages. Franko as a polyglot, who knew Latin and ancient Greek and was fluent in the main European languages, resorted to borrowing words in cases where there were no adequate Ukrainian correspondences, considering it to be a quite natural process (see Figure 1).

Literary language is enriched by the language of talented and popular writers. Franko believed that

"it seems that the speech is something common to all of us, but there is no doubt that as every child in the first years produces its own separate jargon, and every writer, especially talented, produces its own language, has its own characteristic expressions, figures of speech, its structure of phrases, their favorite words" [7, p. 77].

Figure 1.

The sources of the literary language (according to Franko)

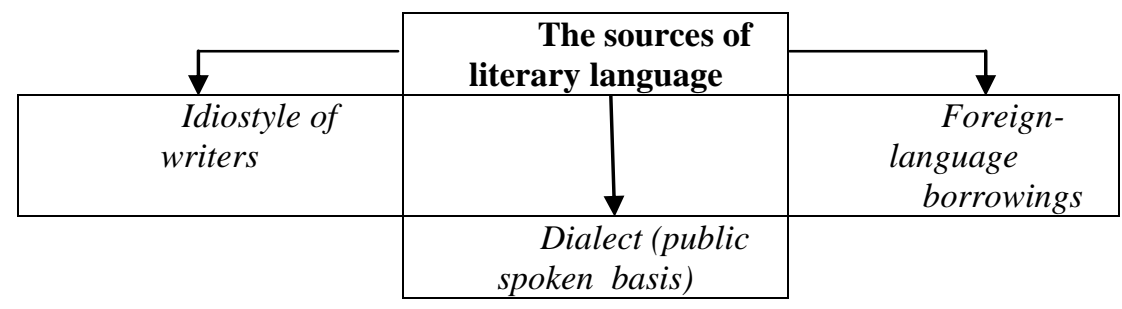

In the above-mentioned work "Literary language and dialects" Franko analyzes the state of the study of boykivskyi, lemkovskyi and hutsul dialects, their impact on the language of Western writers. All this testifies to Ivan Franko's interest in dialect problems and his understanding of the importance of dialect speech for the approval of the unified national language of Ukrainians. It was in this work that 
Franko postulated the thesis that the literary language has deep roots, the source of its creation-a dialect language, without which it would not be so expressive, perfect, rich. He proposed and embodied in the artwork the theoretical foundations of the interaction of the literary language with folk dialects, and pointed to the important role of folk dialects in the formation and functioning of the literary language.

It is important to emphasize the scientific ties of Franko with V. Jagić, Y. Kollar, M. Grushevsky and others, which indicates the interdependence in the problems of formation and functioning of the literary language in Serbia and Croatia, Bosnia and Herzegovina, Montenegro, Slovenia, and Macedonia. To prove these connections, let us recall the theses from the article by Prof. L. Shevchenko on the anniversary of Franko, placed in the publication "Actual problems of Ukrainian linguistics: theory and practice". The scientist emphasizes the exceptional role of I. Franko in the discussion of years 1891 1893, where he denies the advantages of the East Ukrainian literary tradition in determining the direction of the development of the literary language. According to L. Shevchenko, the beginning of the 20th century can be considered as the time when Franko becomes a leader in the formation of priorities for the development of the national language:

"Focusing on the language of his publications and reprints, eager to find new words denoting yet unnamed Ukrainian language concepts in translations, the desire to understand the principles of the formation of the literary language - is not a complete list of work and intellectual quest in the linguistics of Ivan Franko" [8, p. 14].

In the historical-civilizational context, Franko formulates ideas that still get to the attention of ardent supporters and opponents regarding the targeted function of the language, its unified literary form and the "new quality of speech". The author actually left extremely valuable observations about the status and functioning of the Ukrainian language in various areas of public life. The truth of its provisions is particularly palpable during the restoration of social life. It is important to note that the life of the native language, the 
development of the highest and perfect form of the national language - literary, which corresponds to the actual Ukrainian national type and represents national unity. I. Franko associated with active participation in this process, a wide group of intellectuals, scientists, artists, literature, and others.

Franko played an important role not only in the literary language in general but also in the literary scientific speech in particular. The transition from a regional language base to a single Ukrainian literary language, which was developed in the Naddnipryanska Ukraine and established in the works of classics, was a complex process that required, according to I. Franko, a solid scientific knowledge of the processes of historical development of the people, the development of its speech, ways of its enrichment, a knowledge of life itself with its diverse language practice.

"Each literary speech is alive and capable of life as long as it has the opportunity, on the one hand, to assimilate all the cultural elements of modernity, meaning that it has to be enriched with new terms and expressions corresponding to the progress of modern civilization, without spending its main type and without passing into the jargon of some special layers or heaps of people, and on the other hand, while it has a tendency, to be enriched with new elements from people's life and with the differences and dialects of the people's speech" [7, p. 29].

It is known that I. Franko paid much attention to the problems of development of the Ukrainian literary language both in purely linguistic, and in literary-critical articles and studies, reviews of linguistic works preface to various publications, often entered into the linguistic controversy over topical language issues. Interestingly, when assessing the language of writers the main criterion for Franko was the purity, clarity, and accessibility of the literary language. This criterion was adhered to by the writer in his artistic practice, diligently practicing the language of his works, in particular when they were reprinted, and taking care primarily of its clarity in all Ukrainian lands. One of the convincing evidence of such work by 
Franko is, for example, a thorough author's editing of the language of all lifetime editions of the poem "Fox Mykyta", which belongs to the most popular works of the writer. We consider this a prospect for further research in linguistics, showing on the example of fiction literacy the author's attitude towards the exemplary literary language.

The concept of Franko on the formation of a single Ukrainian literary language has found consistent implementation in his own artistic, literary- critical and scientific work, and his language practice. Implementing the basic provisions of his conception of the literary language development - wide use of possibilities of internal language-creative processes, particularly the word formation in the Ukrainian word-creative models, rethinking the meaning of existing lexemes and their use in the secondary nominative functions, tracing of words and turns of speech, which lacked the Ukrainian language lacked, direct borrowings from other languages, the selection of relevant linguistic units of spoken language, including dialect, a permanent enrichment of own literary and linguistic practice I. Franko played an extremely important role in the development of a single literary language, the gradual convergence of the Galician version of the literary language with the naddnipryanske.

So, to all the problems of speech development, including the approval of a single national literary speech, Franko approached from a purely scientific point of view, consistently defended the scientific opinion that the linguistic issue, as well as the national question as a whole, should become components of the general democratic liberation movement, the struggle for broad social and national rights of people.

\section{REFERENCES}

1. Greshhuk, V. (2007). The role of Ivan Franko in forming a united Ukrainian literary language [Rol' Ivana Franka u formuvanni jedynoi' ukrai'ns'koi' literaturnoi' movy]. Visnyk Naukovogo tovarystva im. T. Shevchenka, № 2, 29-37 [in Ukrainian].

2. Jermolenko, S. (2014). Valuable criterion for codification of the literary norm [Cinnisnyj kryterij kodyfikacii' literaturnoi' normy]. Naukovi 
zapysky Nacional'nogo universytetu "Ostroz'ka akademija", 50, 3-7 [in Ukrainian].

3. Kapanajko, I. (2013). The phenomenon of language in the understanding of I. Franko (on the material of the Polish article in the journal "Zyarno") [Fenomen movy v rozuminni Franka (na materiali pol's'komovnoi' statti v chasopysi "Ziarno")]. Studia Ukrainica Posnanensia, vol. I, 75-80 [in Ukrainian].

4. Kononenko, V. (2002). Language. Culture. Style [Mova. Kul'tura. Styl' : zbirnyk statej]. Kyiv ; Ivano-Frankivs'k [in Ukrainian].

5. Literary norm and linguistic practice (2013) [Literaturna norma i movna praktyka] / Ed.: S.Ja. Jermolenko; S.P. Bybyk, T.A. Koc' ta in. Nizhyn: Aspekt-Poligraf [in Ukrainian].

6. Matvijas, I. (2002). Ivan Franko's contribution to the Ukrainian literary language [Vnesok Ivana Franka v ukrai'ns'ku literaturnu movu]. Ukrai'ns'ka mova, 1, 71-77 [in Ukrainian].

7. Franko, I. (1982). Collected works in 50 volumes [Zibrannja tvoriv u 50-ty tomah]. Kyi'v. T. 37 [in Ukrainian].

8. Shevchenko, L. (2011). The Slavic context of Ivan Franko's idea of the nation-building status of the Ukrainian literary language [Slov'jans'kyj kontekst idei' Ivana Franka pro naciotvorchyj status ukrai'ns'koi' literaturnoi' movy]. Aktual'ni problemy ukrai'ns'koi' lingvistyky: teorija i praktyka, 22, 10-18 [in Ukrainian].

9. Yatskiv, N. \& Venhrynovych, N. (2018). Transformation of the French Pattern of a Naturalistic Character in Ivan Franko's Literary Works. Kyiv-Mohyla Humanities Journal. 5, 183-200. https://doi.org/ 10.18523/kmhj150401.2018-5.183-200 [in English].

\section{ЛІТЕРАТУРА}

1. Грещук В. Роль Івана Франка у формуванні єдиної української літературної мови. Вісник Наукового товариства ім. Т. Шевченка. № 2. 2007. С. 29-37.

2. Срмоленко С.Я. Ціннісний критерій кодифікації літературної норми. Наукові записки Національного університету "Острозька академія". 2014. Вип. 50. Серія "Філологічна". С. 3-7.

3. Капанайко I. Феномен мови в розумінні Франка (на матеріалі польськомовної статті в часописі "Ziarno"). Studia Ukrainica Posnanensia. vol. I : 2013. C. 75-80.

4. Кононенко В.І. Мова. Культура. Стиль : збірник статей. Київ ; Івано-Франківськ, 2002. 460 с. 
5. Літературна норма i мовна практика : [монографія] / С.Я. Єрмоленко, С.П. Бибик, Т.А. Коць та ін.; [за ред. С. Я. Єрмоленко]. Ніжин: Аспект-Поліграф, 2013. 320 с.

6. Матвіяс І. Внесок Івана Франка в українську літературну мову. Украӥнська мова. 2002. № 1. С. 71-77.

7. Франко І. Зібрання творів у 50-ти томах. Київ, 1982. Т. 37. 619 с.

8. Шевченко Л.І. Слов'янський контекст ідеї Івана Франка про націотворчий статус української літературної мови. Актуальні проблеми української лінгвістики: теорія і практика. 2011. Вип. 22. C. 10-18.

9. Yatskiv N., Venhrynovych N. Transformation of the French Pattern of a Naturalistic Character in Ivan Franko's Literary Works. KyivMohyla Humanities Journal. 2018. №5. P. 183-200. https://doi.org/ 10.18523/kmhj150401.2018-5.183-200

Дата надходження до редакції - 23.03.2019 Дата затвердження редакцісю - 24.04.2019 